\title{
The importance of sustainability, in libraries in Villahermosa Tabasco, for the design of a proposal
}

\section{La importancia de la Sustentabilidad, en las bibliotecas en Villahermosa Tabasco, para el diseño de una propuesta}

\author{
MOREJON-SANCHEZ, Juana Maríał*, ELISEO-DANTÉS, Hortensia, CABRERA-MORALES, Janet \\ and PAYRÓ-GARCÍA, Génesis
}

Tecnológico Nacional de México, Campus Villahermosa

ID $1^{\text {st }}$ Author: Juana María, Morejón-Sánchez / ORC ID: 0000-0002-9930-181X, Researcher ID Thomson: ABE-28792020, CVU CONACYT ID: 362413

ID $1^{\text {st }}$ Coauthor: Hortensia, Eliseo-Dantés / ORC ID: 0000-0003-4006-4669, Researcher ID Thomson: F-6749-2018, CVU CONACYT ID: 411079

ID $2^{\text {nd }}$ Coauthor: Janet, Cabrera-Morales / ORC ID: 0000-0002-1288-1701, Researcher ID Thomson: ABE-3253-2020, CVU CONACYT ID: 814133

ID $3^{\text {rd }}$ Coauthor: Génesis, Payró-García / ORC ID ID0000-0002-7705- 0028 - Researcher ID Thomson: ABE-2833-2020, CVU CONACYT ID: 1003690

Abstract

Objective. Analyze the Sustainability in the libraries, throught applied research, in Villahermosa City, Capital of the Tabasco State. Methodology. The research is nonexperimental, descriptive and correlational. In this research, the sustainability of libraries is analyzed considering the behavior of the research variable (Sustainability) in the different international, national and local contexts, as well as the theoretical foundations, on which this research variable is based. Then an instrument is designed that was applied to the libraries of the city of Villahermosa, for the collection of information through the Self-diagnosis tool based on ten elements (Measurements related to the end user, Measurements and / or performance of the process, Alliances with providers, Documentación, Training, Benchmarking, Adaptability Process, Cotinuous improvement, Human resource evaluation, Management level evaluation), which generated results on the current situation of the libraries, which served as a basis for their analysis. Contribution. From the results obtained in the application of this instrument, a model was designed to improve the sustainability of libraries, which will allow them to be more competitive in their field.

Sustainability, library, variable
Resumen

Objetivo: Analizar la Sustentabilidad en las bibliotecas, a través de una investigación aplicada, en la ciudad de Villahermosa Tabasco. Metodología. La investigación es no experimental, descriptiva y correlacional. En la presente investigación se analiza la sustentabilidad de las bibliotecas, considerando el comportamiento de la variable de investigación (Sustentabilidad) en los diferentes contextos internacional, nacional y local así los fundamentos teóricos, en los cuales se sustenta esta variable de investigación. Luego se diseña un instrumento que se aplicó a las bibliotecas de la ciudad de Villahermosa, para el levantamiento de la información a través de la herramienta de Autodiagnóstico basado en diez elementos (Mediciones relacionadas con el usuario final, Mediciones y/o desempeño del proceso, Alianzas con proveedores, Documentación, Entrenamiento, Benchmarking, Adaptabilidad del proceso, Mejoramiento continúo, Evaluación del recurso humano, Evaluación del nivel directivo), el cual generó resultados sobre la situación actual de las bibliotecas, lo que sirvió como base para el análisis de las mismas. Contribución. De los resultados obtenidos en la aplicación de este instrumento, se diseñó un modelo para mejorar la sustentabilidad de las bibliotecas, el cual les permitirá ser más competitivas en su ámbito.

Sustentabilidad, biblioteca, variable

Citation: MOREJON-SANCHEZ, Juana María, ELISEO-DANTÉS, Hortensia, CABRERA-MORALES, Janet and PAYRÓGARCÍA, Génesis. The importance of sustainability, in libraries in Villahermosa Tabasco, for the design of a proposal. ECORFAN Journal-Republic of Paraguay. 2020. 6-10: 1-7

\footnotetext{
* Correspondence to Author (email:juamoresan59@ hotmail.com)

$\dagger$ Researcher contributing as first author.
} 


\section{Introduction}

Sustainable development does not debate or discuss political or economic systems, but rather, based on the environment, it postulates a peaceful and gradual social change, which in an organized and planned manner modifies our relationship with nature, with ourselves and with society. In this way, sustainable development has created a great adhesion in its favor because in its discourse it offers central points of consensus that are impossible to reject; however, this is due to a very simple reason: analysis is needed so that the definition is not too broad to be put into practice. The concept is accepted as a social proposal but cannot be easily applied to specific work processes; however, it is its breadth that allows for multiple interpretations regarding sustainability. (IICEMAD-IPN 2003),

The objective of this project is to determine the importance of libraries in Villahermosa Tabasco. Therefore, it is important to consider the different contexts: international and national. As well as the theoretical foundations on which the research variable (Sustainability. Next, the methodology of the investigation is presented, where an instrument for the information survey is designed. Then the results of the research are presented, which will serve as a basis for a proposal, and finally the conclusions of the project are presented.

\section{Background}

The National Public Library Network began in 1983 as one of the central strategies in education and culture promoted by the Mexican government. At that time, Mexico had 351 public libraries throughout its territory, limited for its surrounding population, so it was thought to start a network in each of the states, which in turn was coordinated with a central library in the main cities, with regional libraries in the middle cities and with municipal libraries in small towns. Thus, in 1988, with the formation of the National Council for Culture and the Arts (CONACULTA), the General Directorate of Libraries became part of its structure, and with it, a program for the creation and maintenance of new library spaces was promoted, promoting various actions to solve the country's educational needs.
The Public Libraries of the City of Villahermosa, Tabasco. They generated a determined change from the emergence of the José María Pino Suárez Library, which established some other services not available in those years.

\section{Problem Statement}

Currently, both public and private libraries in Villahermosa Tabasco, do not have automated systems in relation to the organization of their books, have a collection of obsolete books, computer equipment that is not continuously updated, poorly trained staff who really do not know their work as a librarian, deficiency in public service. Therefore, it is necessary to study the importance of sustainability in the libraries in Villahermosa Tabasco.

\section{International Context}

Within the framework of the United Nations High Level Policy Forum (HLPF), which is taking place in New York, the International Federation of Library Associations and Institutions (IFLA), ratified its position regarding the importance of libraries in meeting the United Nations Sustainable Development Goals (SDAs). The role of libraries is key to this issue and as the president of IFLA expressed, "In recent years, IFLA has placed a strong emphasis on the United Nations Sustainable Development Goals. These not only provide a valuable way to raise awareness and advocate for libraries as partners for governments, but also provide a framework for thinking about how libraries can meet broader social priorities. The representatives of the countries of the UN highlight the great work being done at the national level to ensure that libraries are recognized and included in development and implementation plans.

In September 2015, United Nations Member States adopted the document "Transforming our world: the Agenda 2030 for Sustainable Development" (United Nations Agenda 2030). The new UN Agenda 2030 is an inclusive framework, consisting of 17 Sustainable Development Goals (SDGs) covering economic, environmental, and social development. Through the achievement of the objectives of this agenda, no one will be left behind. Libraries are key institutions for achieving these Goals. 
Worldwide, 320,000 public libraries and more than one million parliamentary, national, university, scientific and research, school and special libraries ensure that the information and knowledge to use this information is available to all, making them key institutions in the digital age. Libraries provide infrastructure for information and communication technologies (ICT), help people develop the ability to use information effectively, and preserve information to ensure continued access for future generations. They provide a reliable and established network of local institutions that can reach all sectors of the population.

\section{National Context}

The Miguel Lerdo de Tejada Library is a bibliographic site in Mexico City, located in the Historic Center of Mexico City. It is specialized in economic topics and is under the protection of Mexico's Ministry of Finance and Public Credit at the Antiguo Oratorio de San Felipe Neri. It has a bibliographic collection of 86,350 titles and 114,852 volumes.

With the goal of stimulating the study and documentation of economic sciences in Mexico, in 1928 the then Secretary of Finance Luis Montes de Oca commissioned Jesús SilvaHerzog, then in charge of the Historical Archive of the Treasury, and bibliographer Francisco Gamoneda, to concentrate the different collections related to the economy in Mexico's history, such as the Real Hacienda of the 18th century and the Public Treasury of the 19th century from independent Mexico.

The site chosen for the new collection was the Empress Chapel of Palacio Nacional, where Gamoneda ordered a carved wooden shelf similar to the Escorial Library in Spain. The library was opened to the public in October 1928. In 1957, on the occasion of the centenary of the Reform Laws, it was named after Miguel Lerdo de Tejada, in homage to the man who occupied the position of public treasurer during the presidencies of Ignacio Comonfort and Benito Juárez. Given the library's growing collection, in 1970 it was moved to the main nave of the former Oratorio de San Felipe Neri "El Nuevo", on República de El Salvador Street, where it remains to this day.
The newspaper collection includes diverse newspapers and magazines, which are integrated to diverse collections and temporalities, ranging from the newspapers and magazines of the Reserved Fund of the 19th and 20th centuries, to contemporary periodical publications, such as the newspapers La Jornada, Milenio, Revista Proceso, Artes de México, to name a few.

\section{Theoretical Foundations}

\section{Sustainability}

According to Juarez. 2011, Sustainability is the continuous improvement that allows to satisfy the current needs without compromising the capacity of future generations to satisfy their own. Suárez, 2014, defines sustainability as an individual way of life that starts in a particular way until arriving in a general way to sustainable development as the development that satisfies the needs of the present without compromising the capacity of future generations to satisfy their own needs. Sustainability is actually "a process" that aims to find a balance between the environment and the use of natural resources. (Group, 2013). Sustainable development refers to the ability of the human system to meet the needs of present generations without compromising the resources and opportunities for growth and development of future generations. According to Méndez 2014, sustainability is the ability to achieve sustained economic prosperity over time while protecting the planet's natural systems and providing a high quality of life for people.

Social sustainability is based on maintaining social cohesion and the ability to work towards common goals. It would mean, taking the example of a company, taking into account the social consequences of its activity at all levels: workers (working conditions, salary level, etc.), suppliers, customers, local communities and society in general. It refers to adopting values to maintain a good standard of living in the population of a country, in the social aspects either the enrollment of the same people to create something new in the society where they are part (Instituto Nacional y Geografía e Informática, Mex. 2000) 


\section{Research methodology}

The research is non-experimental and descriptive and consists of getting to know the situations, customs and predominant attitudes through the exact description of the activities, objects, processes and people. Its goal is not limited to data collection, but to predict and identify the relationships that exist between two or more variables. (Dalen and Meyer 2006). For the research, an instrument was designed that is used in the Self-Diagnosis tool, Integral Instrument for the Measurement of Productivity (IIMP) of the Libraries subject to the studies, where the ten elements are measured ( Measurements related to the final user, Measurements and/or performance of the process, Alliances with suppliers, Documentation, Training, Benchmarking, Adaptability of the process, Continuous improvement, Evaluation of the human resource, Evaluation of the managerial level), with each one of the sub-elements as shown in Table $\mathrm{N}^{\circ} 1$ and No. 2 of this research, where only 2 of the 10 elements mentioned are shown. The purpose of this instrument is to obtain information related to the advances achieved in the Integral scheme of the system, while it is useful as a selfdiagnosis for the organization as a first aspect. Meetings were held with eight libraries to gather information, but for the subject of this research, only two libraries were subsequently contacted and used as samples. The Delphi method was used to meet with experts from these libraries.

\section{Instrument}

Instructions:

Below are questions in each of the elements referring to the company, which integrate it, mark with an " $\mathrm{X}$ " under the number you consider convenient.

Integral Instrument of Self-Diagnosis of Productivity (IIMP).

\section{Element 1 End-user related measurements}

Objective: To know all the aspects related to the client and that impact the processes of the organization

\begin{tabular}{|c|c|c|c|c|c|c|c|c|c|c|c|}
\hline & & & & vanc & s in & & & & & & \\
\hline & $\begin{array}{l}\text { Sub-element } \\
\text { Description }\end{array}$ & 10 & 20 & 30 & 40 & 50 & 60 & 70 & 80 & 90 & 100 \\
\hline 1 & $\begin{array}{l}\text { Do you have } \\
\text { well defined, } \\
\text { who are your } \\
\text { users? }\end{array}$ & & & & & & & & & & \\
\hline 2 & $\begin{array}{l}\text { Do you have a } \\
\text { method, } \\
\text { which } \\
\text { provides you } \\
\text { with updated } \\
\text { information, } \\
\text { to know the } \\
\text { needs of your } \\
\text { users? }\end{array}$ & & & & & & & & & & \\
\hline 3 & $\begin{array}{l}\text { Do you have } \\
\text { any system or } \\
\text { programs that } \\
\text { provide staff } \\
\text { skills for user } \\
\text { care? }\end{array}$ & & & & & & & & & & \\
\hline 4 & $\begin{array}{l}\text { Do you have a } \\
\text { process to } \\
\text { receive and } \\
\text { solve possible } \\
\text { disconformiti } \\
\text { es of the } \\
\text { users? }\end{array}$ & & & & & & & & & & \\
\hline 5 & $\begin{array}{l}\text { Do you have a } \\
\text { system to } \\
\text { know if the } \\
\text { user is } \\
\text { satisfied with } \\
\text { your services? }\end{array}$ & & & & & & & & & & \\
\hline 6 & $\begin{array}{l}\text { Do you have a } \\
\text { process that } \\
\text { allows them to } \\
\text { compare the } \\
\text { practices of } \\
\text { your system } \\
\text { with other } \\
\text { agencies? }\end{array}$ & & & & & & & & & & \\
\hline 7 & $\begin{array}{l}\text { Do you have } \\
\text { programs to } \\
\text { empower the } \\
\text { staff in } \\
\text { contact with } \\
\text { the user? }\end{array}$ & & & & & & & & & & \\
\hline 8 & $\begin{array}{l}\text { Do you have } \\
\text { indicators of } \\
\text { effectiveness } \\
\text { and efficiency } \\
\text { in relation to } \\
\text { users? }\end{array}$ & & & & & & & & & & \\
\hline
\end{tabular}

Table 1 Integral instrument for the measurement of Productivity, element 1.

Source: Author's Perception 2020

\section{Integral Instrument of Self-Diagnosis of Productivity (IIMP).}

\section{Element 2. Process Measurement and/or Performance}

Objective: To analyze integrally each one of the actions that are developed in the processes and their interrelation among them, for the achievement of the integral objective 


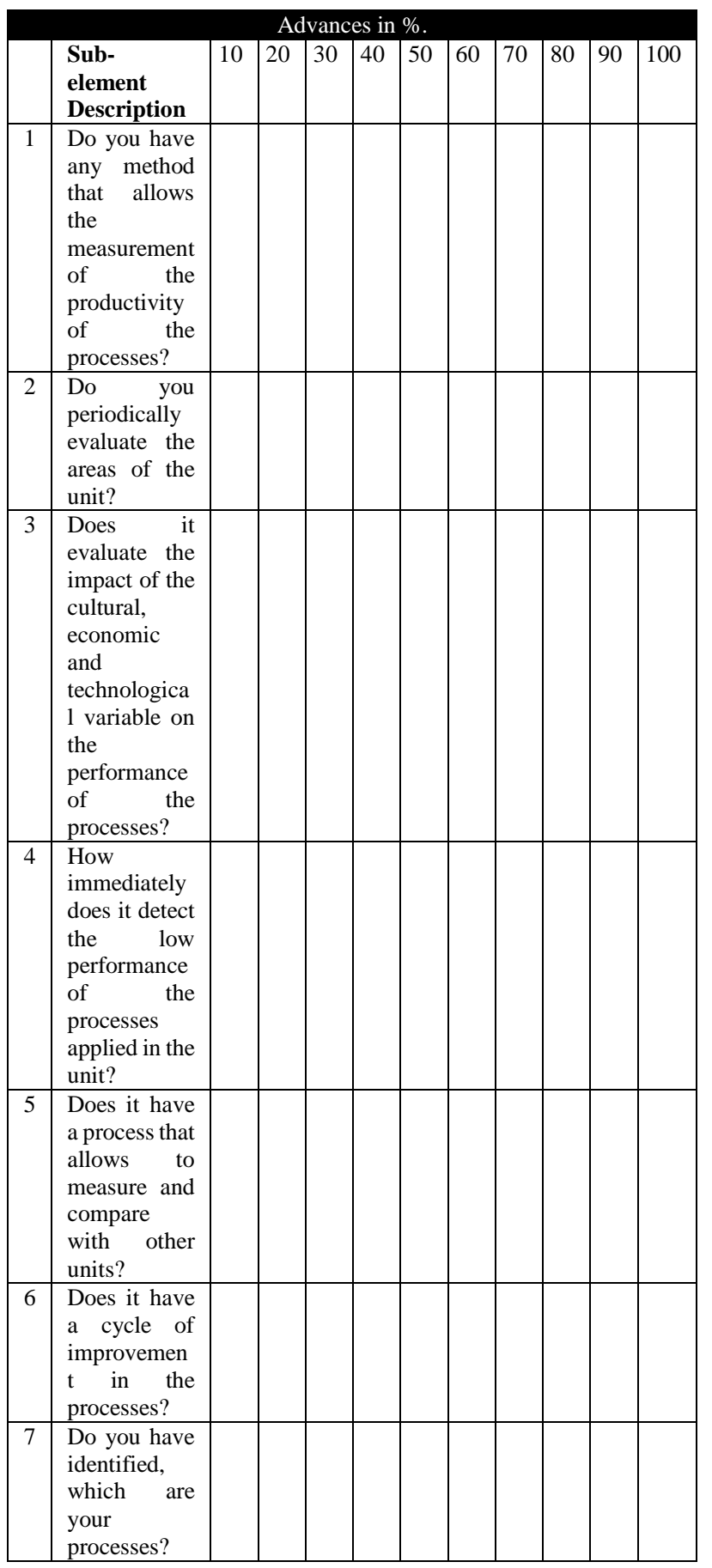

Table Integral instrument for the measurement of Productivity, element 2

Source: Author's Perception 2020

There were 7 areas that the instrument was applied: Management, INEGI area, general area, Newspaper library area, computer area, children's area and consultation area. Graphs 1 and 2 show the first two areas. Where the evaluation criteria and the ten elements to be considered in the self-diagnostic tool (IMPP) are given

\begin{tabular}{|l|l|}
\hline \multicolumn{2}{|c|}{ Measurement Elements } \\
\hline $\mathbf{1}$ & Related measurements \\
\hline $\mathbf{2}$ & Measurement and/or performance \\
\hline $\mathbf{3}$ & Alliance with supplier \\
\hline $\mathbf{4}$ & Documentation \\
\hline $\mathbf{5}$ & Training \\
\hline $\mathbf{6}$ & Benchmarking \\
\hline $\mathbf{7}$ & Process adaptability \\
\hline $\mathbf{8}$ & Continuous Improvement \\
\hline $\mathbf{9}$ & Human resource evaluation \\
\hline $\mathbf{1 0}$ & Management level assessment \\
\hline
\end{tabular}

\section{Address}

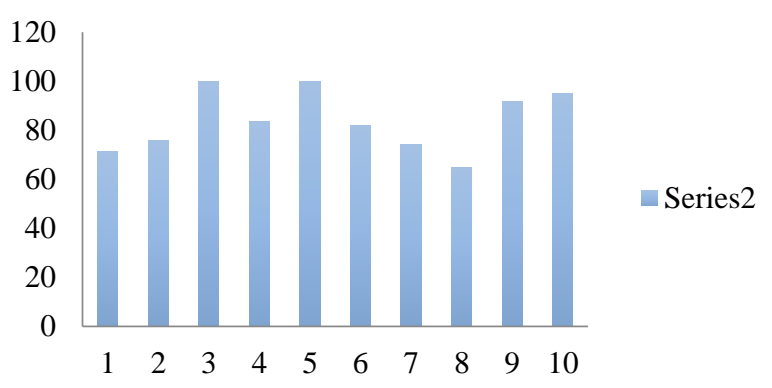

Graphic 1 Management Department

Source: Author's Perception 2020

\section{Overall Average 83.9 Under developmen}

In this Graphic 1, using the ten measurement elements, a percentage of $83.9 \%$ was obtained where it can be determined that the development scale measurement is high and indicates a favorable development in the libraries.

\begin{tabular}{|l|l|}
\hline \multicolumn{1}{|c|}{$\%$} & \multicolumn{1}{c|}{$\begin{array}{c}\text { Dependency } \\
\text { Development Scale }\end{array}$} \\
\hline $10-30$ & Primitive \\
\hline $40-50$ & Initial \\
$60-80$ & In development \\
$90-100$ & Focus on productivity \\
\hline
\end{tabular}

\section{INEGI}

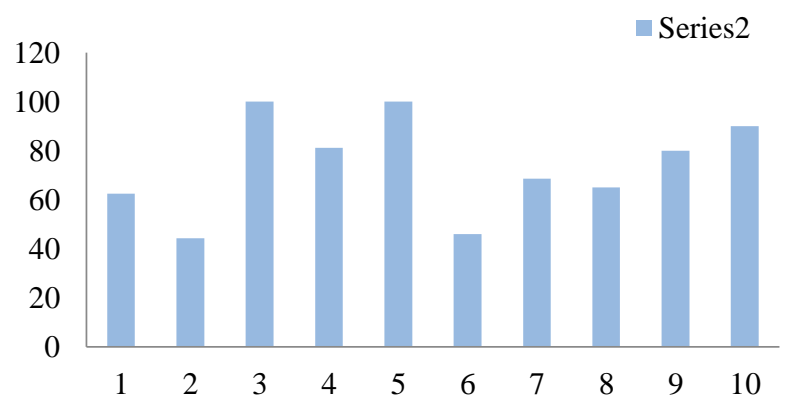

Graphic 2 INEGI Area

Source: Author's Perception 2020 
In this area of INEGI, the result that was obtained, before the application of the elements to the libraries, was of a percentage of $73.8 \%$ in this area like the past area, the scale is of development indicating that it is in a stable productivity.

\section{Results}

In figure 3 , the integral profile of each of the 8 areas that were considered of the libraries is shown. The same evaluation criteria were used and the 10 elements considered in the selfdiagnostic tool shown in Graphic 1.

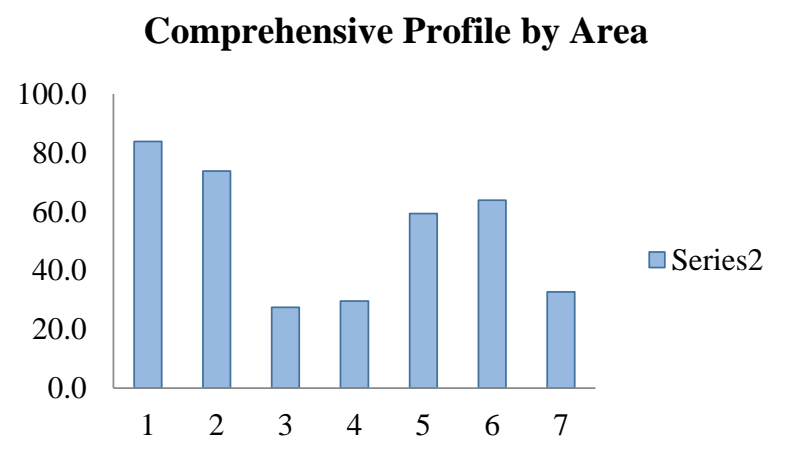

Graphic 3 Library Areas

Source: Author's Perception 2020

In this Graphic 3, the result of the areas of libraries, you can see that the overall average per element is $87.1 \%$, placing the different areas in full development of productivity.

\section{Overall Average 87.1 Initial}

Figure 4 shows the Comprehensive Profile by element of the 10 elements of the Comprehensive Productivity Self-Diagnostic Instrument (IIMP).

Integral Profile by Element

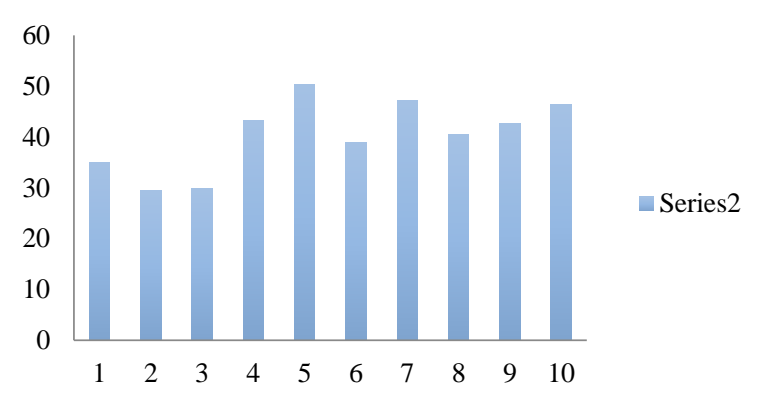

Graphic 4 Library Areas

Source: Author's Perception 2020
In Graphic 4 it can be seen that the general average per element is $50.9 \%$, which indicates that there is an initial development as a result of the application of the Self-Diagnosis instrument.

The measurement instrument was applied to the managers and to each of the persons responsible for the different areas of the libraries. They were interviewed in order to know the possible problems that require due attention, for an improvement in the dependence and to be able to know their strengths and reinforce them for a growth in productivity.

Through the self-diagnosis carried out on the libraries, it was possible to identify their strengths and weaknesses in a comprehensive way, as well as to know their deficiencies or shortages in the various organizational, administrative, commercial and operational procedures. The self-diagnosis also serves to identify the actions that must be executed to comply with current legislation, planning processes and good governance of the unit and the progress in the execution of the business plan in the short, medium and long term. A major deficiency was found that affects the performance of the entire unit, the dissatisfaction of users and the same people in charge of the various areas of the libraries.

\section{Conclusions}

Derived from the self-diagnostic instrument where the sustainability productivity was measured and where it was determined that the servers do not have a specific information and do not know if the client or user has a quality service. And that most of them do not have a web page. The areas of the libraries should be strengthened, since this is reflected in the instrument used with $87.1 \%$ which indicates that they are under development, so it is proposed to strengthen with updated software, updated bibliographies, improvement in customer service. In the analysis of the 10 elements, it shows a $50.9 \%$, which indicates that there is an initial development in the libraries. It is necessary to strengthen the measurements related to the client, measurements and/or performance of the process, as well as its Alliances with suppliers. 


\section{References}

Albert G. H. Luis Zuñiga L. (2012). El Desarrollo Sustentable y las organizaciones Mexico: Sauyed.

Blauert, Jutta y Zadek, Simon. Mediación para la sustentabilidad, The British Council, México, 1999, p. 9.

Barkin, David: Superando el paradigma neoliberal. Desarrollo popular sustentable, Porrua, México, 2001, p. 336.

Calvente, A. M. (2007). El concepto moderno de sustentabilidad . mexico.

Carvajal Hormaza Héctor Libardo. 16 de marzo 2004

http://www.dgire.unam.mx/contenido_wp/bibli otecas/tipos-biblioteca.html

Coutiño, R. D. (2012). Desarrollo sustentable: una oportunidad para la vida. D.F.: McGraw Hill.

Enkerlyn, H. Ernesto. El desarrollo sustentable ¿El paradigma idóneo de la humanidad? ITM, México, 1997, p. 511.

Enkerlyn, H. Ernesto ibíd, p. 511-512. https://www.esan.edu.pe/apuntesempresariales/2017/02/el-autodiagnostico-unamirada-hacia-el-interior-en-la-empresa/

Juarez, G. D. (2011). Desarrollo sustentable en el contexto actual. Mexico: McGill.

Juliet Beth Zimerman, James R. Mihelci. (2015). ingenieria ambiental. mexico : Alfaomega.

Mendez, I. A. (2014). definicion integral de una sociedad sustentable. Un mejor mundo, 16 y 17.

Suárez, M. V. (2014). Dasarrollo Sustentable. Mexico: Grupo Editorial Patria.

Torres, E. G. (2011). Desarrollo sostenible. mexico: Alfaomega. 